\title{
DEFENSE INVESTMENT AND RECONSTRUCTIONING INDUSTRY: VISION 2023 OF TURKEY
}

\author{
Ali Duran Uzun \\ Dr., Economist, Adana / Turkey \\ aliduranuzun@gmail.com \\ İran Kalaycı \\ Prof. Dr., Dep. of Economics, Inonu University, Malatya / Turkey \\ irfan.kalayci@inonu.edu.tr \\ Onur Demirci \\ Research Assis., Dep.of Economics, Ardahan University, Ardahan / Turkey \\ onurdemirci@ardahan.edu.tr
}

\begin{abstract}
Each country has to reserve a share optimum amount of defense investment from the budget. If a country's defense is inadequate, other investments will remain to be an inadequate level in the country. World military expenditure in 2016 totaled about $\$ 1.68$ trillion, around 2.2 percent of world GDP. From 1945 to the day extraordinary advances in military technology occurred made it mandatory new investment and reconstructions in the defense industry. Highly competitive inter/national large corporations should be established in the defense industry as USA and Europe made mergers. The biggest defense spenders in 2016 were respectively USA, China, Russia, S.Arabia, India. To Turkey's 2023 vision, with rational defense investment will be an important contribution as developing the economy and the industry and the technology level. Due to the neighbor, the amount of aid given to housing and health care and employment for 3.5 million refugees who fled the civil war in Syria, is over $\$ 25$ billion. As taking consideration with existing defense potential of Turkey, It must be taken sample that countries, obtaining social-economic utulity from defense investment.
\end{abstract}

Keywords: Defense Spending, Vision 2023, Scale Economies, Critical Technology, Dominance Doctrine.

Jel Codes: L64, O14, O25

\section{Introduction}

The concept of defense, has maintained its importance in every period of human history and primitive weapons, consist of sharp stones and spears, left their position to nuclear weapons. Threat and risk perception in the new world system is of paramount importance. Supply and to establish peace is possible with a strong defense industry and a modern army. Rapidly changing world for the future is full of uncertainty. So defense; is to take a precaution for the indefinite future. Deterrence is the basis for the defense. Quality people, superior doctrine, superior technology and ready forces are indispensable character of Army.

The defense industry; producing and developing the equipment and weapons systems for all kinds of strategic and tactical objectives, to be ready at any moment a potential threat, risk and attack, the economies of countries, the scientific potential of the workforce, the military- 
political-strategic-academic concept, with composition and other industry branches, is engaged in manufacturing facilities and community collaboration. All of the country's industry should be accepted as part of the defense industry and other industries with the integration of the defense industry should do in a short time. Otherwise, the cost is being opened up to very high levels lead to making production, leads to waste of economic resources.

Defense industry, including the developed countries in particular, has an important place in the world in general economic activity. Beginning in 1970 the world's total defense spending has increased substantially. The end of the Cold War and reconstruction results in Eastern European countries, the resources used for military spending shifted to other areas, and thus defense spending reduced. World defense spending decreased from $\$ 1.2$ trillion to $\$ 865$ billion between 1990-1995. September 11, 2001 terrorist attacks in the US, intervention in Afghanistan and after war in Iraq, by increasing US defense spending it increased to $\$ 1,2$ trillion in 2006. In 2013, world military spending has risen to about \$ 1.75 trillion.

Having been directed of defense investment to the defense systems will be developed as a national and producted for export; as it would contribute to the promotion of technology and industrialization capabilities, the country's science, the country's economic competitiveness and will also increase the deterrence in the military field.

Supply-demand relationship, which applies to all other economic systems are also valid for the defense industry products. On the demand side often has the state as the sole buyer has formed an oligopoly of large enterprises on the supply side. Therefore, product quality and price can be adjusted as desired.

The US Reagan era marked the foreign policy 'Hawks Group' launched towards the end of the eighties "Star Wars" project with armament technological and financial aspects of the well has grown. In this case, the United States has led to the collapse of the high external debt and has reached the returned though ultimately aim as inflation and such a phenomenon in the same way outsourcing deprived Soviet block can not respond with a debt and the world is unipolar has transformed into a structure (Coşkun, 1998).

Today, when Orion's travel and space mining discussed, Vision 2023 is one of the most important aspects that determine the direction of defense investment for Turkey. After a century, the establishment of the Republic of Turkey on 29 October 1923, designated national strategies (Vision 2023) are;

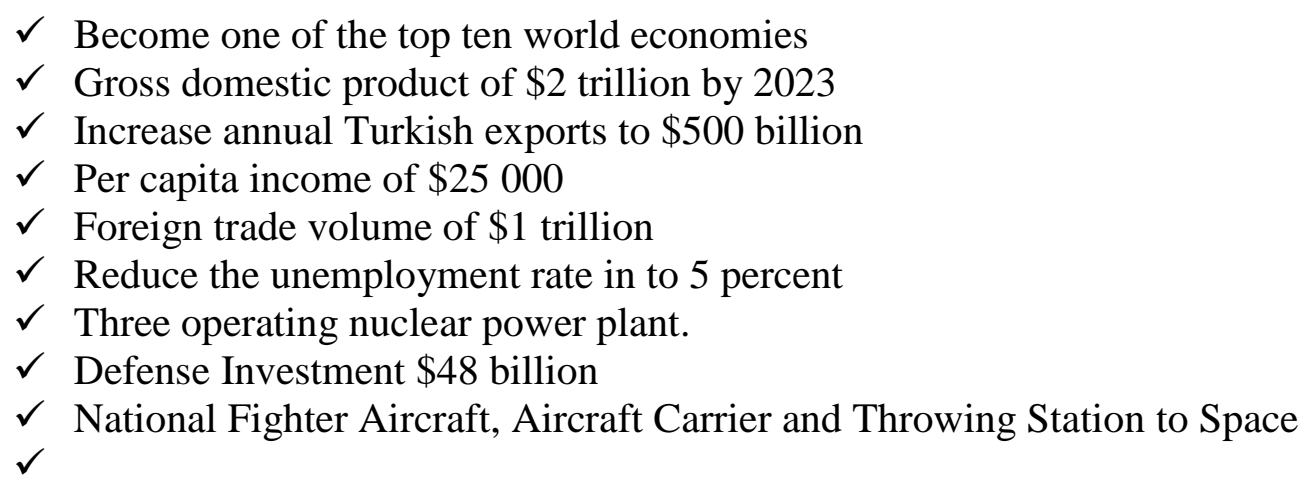

Dominance doctrine; are strategies to dominate the world. Naval forces and maritime dominance theory, Land power and land domination doctrine " Heartland Theory " ... space 
come to the fore. In this regard, in 1936, saw the future and the future of the country's aviation sector Atatürk says: 'Someday Man will walk in the sky without aircraft, going to go the planets, perhaps, will send us messages from moon. This miracle will not wait for the two thousand years to realize incontinence. Emerging technologies announces it to us ready. Our duty is to provide more on this subject dating back to the West '. Technology provides a competitive advantage.

\section{Literature Review}

Theoretically, the impact on economic growth of defense spending, take some positive externalities supply attempts to explain the bias factor The Military Keynesianism approach and negative externalities base to take demand including Approach Neo-Classical attempts to explain the bias factor, there are two different approaches.

Scientific studies on the relationship between military spending and economic development; according to Benoit (1978) the most important areas are expected to contribute to the defense industry to the technological level of the country. To be produced with very advanced technology of defense products will therefore accelerate the widespread use of modern technology in the production structure.

With a significant portion of the defense spending of the studies in the literature have described the interaction between economic development basing on certain criteria. Among these criteria; savings and investment levels, foreign exchange gains, import flexibility, the efficiency of investment, production capability, sophistication considered. National security, defense industry will be encouraged to increase the private sector investments and a direct contribution to the economy suggests. Examples of Lebanon; First, the sense of security brought about by the military expenditure in the low level as a benefit that provides a positive impact on the economy. And then, the increasing amount of military spending, mentioned the impact on the economy due to the weight gain, the use of factor supply is returned to the negative and experienced in the absence of a sense of security. Hence, economic collapse occured.

High levels of savings and investment in countries with positive economic growth of military spending, stated that an insignificant effect in other countries (Frederiksen \& Looney, 1986). Made by Looney (1989) in the study; the countries, producers and non-producers (importers) are separated and manufacturer of military spending in the country has reached the conclusion that the positive effects on the economy.

The existence of military spending has concluded that vary from one country to the impact on the economy. In a number of studies have concluded that the negative impact of defense spending on economic development (Chowdury, 1991). Defense investments in developing countries, which have different characteristics compared to developed countries; not performed due to the economic and strategic factors play an important role in determining the sense of being threatened by the level of investment security needs. The heavily indebted countries and the very small economic volume of military spending has been observed to be less than in other countries (Hewitt, 1991).

Dritsakis (2004) investigated the relation between the defense expenses and the economic growth between the years of 1960 and 2001 in Turkey and Greece, by Johansen co integration test and vector error correction models; he couldn't find co integration between the defense 
expenses and the economic growth. As a result of Granger causality test, there arose unidirectional causality from the growth to the defense expenses. Özsoy \& İpek (2010) examined the rate of Defense Spendings in the GDP, and the growth rate of GDP, and the portion of current accounts in GDP and Annual Inflation Rate are examined with getting the annual data between the 1980-2006 years, and using VAR model for Egypt, Israel, Jordan, and Turkey. They reached Turkey`s growth rate is affected negatively. For Egypt and Jordan, the significiant effects on defense spendings according to macroeconomic variables couldn't be found any significiant effects.

In this study, it is observed that Defense spending has positive impact on economic growth in high- income countries and negative effects on low- and middle- income countries. This paper focuses on macroeconomic effects of defense investment; in order to realize Vision 2023 aim. For this, industry must be reconstructioned and provided entegration with world.

Turkey's Defence Policy is based on "peace at home, peace at world" and "zero problems with neighbors" as a part of "sustainable improvements" strategy. Acording to this, the main objective is making defense investment on time to support economical growth and social development with various reasons such as reducing import dependency of defense, providing energy supply safety, diminishing possible load on balance of payment, compensating deficits, increasing productivity, providing employment, with minumum cost, equilibrium of defense supply-demand.

In civil sector the usual giant multinational organizations are not frequent in the defense sector. Get in the GATT, and in the Rome Treaty, the defense industry has been left under the umbrella of protectionism. US companies are in the negative, declining profits, employment and sales across the solution by adopting the giant mergers have access to the profitability of up to $7 \%$.

\section{The Methodology}

The purpose of this study is to explain Defense Invetment's features and macroeconomics effects. First of all, frame to obtaining data and findings, SWOT analysis will be done, and then, the road map will be drawn for Turkey direction of "Vision 2023" with statistic.

It is very difficult to tell whether there is relationship between defense investment and economic growth or not; however, research reveals that the defense investments vary from country to country. In this study, modeled on the defense economy through investments in developing countries "how should Turkey make their defense investments?" will be sought to answer the question.

Moreover, in order to answer how OYTEP plans and Independence of Defense decreases in 2023 as optimum. The world's eighth-powerful, in terms of number of troops NATO's second and largest army in Europe with Turkey, $48 \%$ of the main weapons system and equipment are supplied from abroad. In order to ensure the continuity of peace and deterrence, each country has to reserve a share optimum amount of defense investment from the budget. If a country's defense is inadequate, at the same time, other investments will remain to be an inadequate level in the country.

In accordance with the requirements of the era's defense industry restructuring in order to achieve economic growth; Economic characteristics of the defense industry, market characteristics, characteristics of the product, the characteristics of firms that examined factors 
that determine the location of their defense investments irdelenip defense investments and economic effects will be explained. Turkey and defense spending in the world obtained by evaluating the results of work will be completed in the light of findings.

\subsection{Determinants of Defense Investment}

The issues that determine defense investments is examined; Geographical location of the country, Area and boundary the length of the country, Country's risk and threat perception, Defense spending of neighboring countries, Foreign policy and strategy of the country, Major industrialized and developed countries' domination doctrine, International relations, Ability to export of defense materiel, Polity of the country, Development level of the country, Population, The need for energy and raw materials, Technology level, Company size, Critical inventory levels and storage, High quality standards, Skilled labor requirements, The length of time to using major weapons system and modernization, High initial costs, Finance, Projectbased production, Smart and expensive systems, Evaluation and test facilities, Dual use and the market structure of the products determine the direction and level of investment.

\subsection{SWOT Analysis}

Turkey, in terms of geopolitical and geostrategic, is located on an extremely important region. In the new world order serves as a global energy corridor. In this context, the effective macroeconomic strategy and policies can be contributed economic growth with defense investment. In this frame ; (see fig.1)

\begin{tabular}{|c|}
\hline STRENGTHS \\
\hline $\begin{array}{ll}\text { - } & \text { Young and Dynamic } \\
& \text { Populations } \\
\text { - } & \text { Big/Strong Army } \\
\text { - } & \text { Bridge (Asia, Europe) } \\
\text { - } & \text { Global Energy Coridor } \\
\text { - } & \text { Water Potential }\end{array}$ \\
\hline OPPORTUNITIES \\
\hline $\begin{array}{ll}\text { - } & \text { Deterrence } \\
\text { - } & \text { Know-How Technology } \\
\text { - } & \text { Employment } \\
\text { - } & \text { Dualism } \\
\text { - } & \text { Developing Industry }\end{array}$ \\
\hline
\end{tabular}

\begin{tabular}{|c|c|}
\hline \multicolumn{2}{|l|}{ WEAKNESS } \\
\hline $\begin{array}{ll}\text { - } & \text { Neighbc } \\
\text { - } & \text { Critical } \\
\text { - } & \text { Depend } \\
\text { - } & \text { Sea anc } \\
\text { - } & \text { Critical } \\
\text { - } & \text { High Ini }\end{array}$ & $\begin{array}{l}\text { vith ten countries } \\
\text { chnology } \\
\text { cy } \\
\text { and Border } \\
\text { ck } \\
\text { Costs }\end{array}$ \\
\hline THREATS & \\
\hline $\begin{array}{ll}\text { - } & \text { Terorisn } \\
\text { - } & \text { Neighbc } \\
\text { - } & \text { Domina } \\
\text { - } & \text { Unstabi }\end{array}$ & $\begin{array}{l}\text { efense Spending } \\
\text { Doctrine }\end{array}$ \\
\hline
\end{tabular}

Figure 1. Sample SWOT Analyisis

\subsection{Defense Potential of the World and Turkey}

The Ottoman Empire were thought to making information and technology transfer for the first time as a result of the European II of Vienna defeat in 1683. The army and navy breeding. The amount of expenditures for Ankara Wind Tunnel, then state budget 1 / 3rd as is apparent from the documents (Ziylan, 1999).

Belonging to the first Turkish Air Force bomber aircraft used by the first bombs are made in Turkey. $100 \mathrm{kgs}$., $300 \mathrm{kgs}$., $500 \mathrm{kgs}$. and $1000 \mathrm{~kg}$ aircraft bomb and several fire bombs were produced in series in Sakir Zümre factory. Greece has exported 1.5 million pounds of bombs. 
Moreover, in the face of German attacks, was purchased by Poland. In the Second World War, Factory were employed 2000 workers in the factory (Blow, 2005).

However, since the 1950s, the last 24 years in 1974 to Cyprus Peace Operation, mobility has completely stopped. In 1974, Cyprus Peace Operation enacted after the US arms embargo; she reveals the truth can not be left dependent on foreign and defense industry 'make your own aircraft' under the slogan Turkish Aircraft Industries, Inc. (TAI) has been targeted by establishing the aircraft, the Air Force will need to be produced in Turkey (Çağlar, 2000).

Turkey recently demonstrated the participation of the international large-scale projects. JSF (Joint Strike Aircraft) the cost of the program according to the program manufacturer for \$ 145 billion, \$ 220 billion is also according to the American Court of Auditors. Program initiated by the US Canada, Denmark, Norway, the Netherlands, Israel, as well as participated in Turkey in 2000.

The majority of defense spending in Turkey is being undertaken by the government. Apart from a variety of external loans and grants are also among other financing sources. World Bank and IMF loans outside the United States and the military from Germany - is received economic aid and loans. Another funding source in the NATO infrastructure assistance to NATO member countries. Turkey, since 1953, is located in the NATO infrastructure program. Turkey's contribution to the program, while less than $1 \%$, and $14 \%$ of the funds are spent for Turkey. Turkey was declared a total market volume of $\$ 150$ billion over 30 years as stipulated. Purchase $\$ 5$ billion per year, in fact, occurred around $\$ 4 \pm 1$ billion considering the past year.

After the Second World War aviation is changing very rapidly and developed. The most important consequence of this development is the development of commercial aviation. The next 20 years, air transport is expected to grow like 6,2\% per year. In 2003, was 156,5 billion dollars, in 2025 air transport, is expected to be over 518,7 billion dollars. Three country in the world between 1990-1993 US 273, Russia 200, China 190, while European countries could only buy 80 supersonic bomber (Caşın, 1995). Today in the US and among countries capable aircraft outside Russia, France, Germany, Britain, Italy and Sweden are entering a tendency to reduce the production numbers. To further 7 countries mentioned above, the annual production of the aircraft between the years 1973 to 1982, while in 1080 this figure has dropped to 88 combat aircraft 1997 to 2000 . Only Russia has reduced its annual production of 20 aircraft to 614 aircraft in the same period. This trend inflationary pressures companies considering negative effects on the country as a manufacturer of export-led companies to shift from competition is reinforcing.

Despite the economic crisis of the late 1990s, political, military and commercial space activities are increasing globally. Economic crisis is a very large impact on the defense industry. For the US aerospace industry (military, civil and commercial) annual expenditure has exceeded 80 billion dollars. Aerospace industry only employs 500 thousand people in the United States. From 1959 to the end of the 1990s, the US national space assets is approximately $\$ 8$ trillion. Finally, it uses $80 \%$ of the US armed forces during Operation Iraq satellite communications were carried out by commercial satellites. Now the battle is in the electromagnetic field. The name of the last Gulf War in "the first information war" is.

Skills they have gained in the space of states; political, military, and many convenience and advantage in other fields of activity brings. US military space spending on national security is 
around 13 billion dollars. Again over the next 10 years is estimated to be the total expenditure in this area, with $\$ 50$ billion in economic and security reasons. In the period up to 2025 will increase by between $200 \%$ and $300 \%$ in investments for the launch is foreseen. When World military space activities are examined, after so many years spent billions of dollars, reached this conclusion an expensive experience (Canan, 2004).

Seas, military and economic wealth every period of history has been the source of civilization (Efe, 2002). Performs $90 \%$ of foreign trade by sea Turkey, using the opportunities provided by the national industry, especially big progress towards the shipyards to build their own ships were recorded. Aircraft carriers are the world's largest combat ships. US Navy's nuclear-fuel powered aircraft carrier project, 50 years [half a century] is based on a service life of the target and US Navy; year in the inventory of the nuclear aircraft carrier fleet 10-12 are forced to spend 19 billion dollars.

When we look at the post-cold war with the general lines of the world's defense industry has started to decrease and the upward trend after 2001. The balance of the bipolar world collapsed, particularly the United States, Britain, France, Germany, Russia and especially China, have access to a competitive defense industry products marketing. In particular, the share of the 11 September 2001 attacks in the increased competition is great. It attacks in conjunction with the US defense budget has raised over $\$ 400$ billion. This large increase in the United States and the resources allocated to $\mathrm{R} \& \mathrm{D}$ in the defense budget, defense spending has reduced the concerns of the EU. England and France have decided to increase their defense budgets. Also, in the aerospace field in order to maintain the competitiveness of Europe, where a resource requirement of 100 billion euros have been identified.

World Military Expenditure was $\$ 1686$ billion in 2016, total military spending accounted for 2.2 per cent of the global GDP in 2016 \$ 1.75 trillion, around 2.4 per cent of world GDP. (See fig.2)

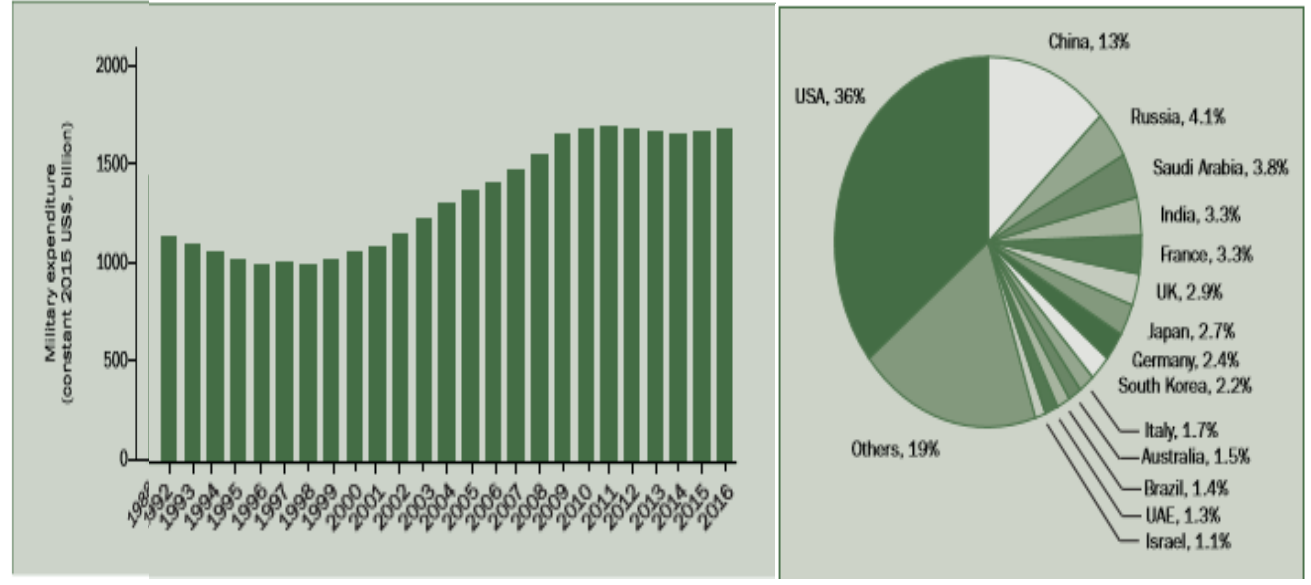

Figure 2. World Military Expenditure (1992-2016), defense spenders 15 countries (2016) Source: SIPRI, www.sipri.org

The 15 largest spenders account for $\$ 1360$ billion, or 81 per cent, of total global spending. USA and China have approximately half (\% 49) of total global spending. The six biggest spenders in 2016 were the United States, China, Russia, Saudi Arabia, India and France. In 2016 , total US military expenditure of $\$ 611$ billion is over one-third (36 per cent) of world military expenditure. This is nearly three times the level of China's spending, which is ranked second. Between 2007 and 2016, China has seen the biggest growth in military spending, with an increase of 118 percent, followed by Russia ( 87 percent) and India (54 per cent). In the 
same period, Italy ( -16 per cent), the United Kingdom ( -12 per cent) and the United States (4.8 per cent) were the only countries in the top 15 to see their military expenditure fall. Russia's military spending increased by 4.8 percent, and for the first time since 2003 it spent a bigger share of its GDP on the military than the USA. Saudi Arabia was the fourth biggest spender in 2016, having ranked seventh in 2012. The United Kingdom has now fallen to eighth place.

There were also several changes in order. Most notably, Saudi Arabia climbed from seventh to fourth place, having increased its military spending by 14 per cent in 2013. Among the lar gest spenders, Saudi Arabia has by far the highest military burden - that is, military spending as a share of GDP. At 9.3 per cent, it is also the second highest (after Oman) for any country for which SIPRI has recent data.(see Table.1)

Table 1. Per Capita Military Expenditure (1990-2016)

\begin{tabular}{|c|c|c|c|c|c|c|c|c|c|c|c|c|}
\hline Country & 1990 & 1995 & 2000 & 2005 & 2009 & $\begin{array}{c}201 \\
0\end{array}$ & $\begin{array}{c}201 \\
1\end{array}$ & 2012 & 2013 & 2014 & 2015 & 2016 \\
\hline Canada & $\begin{array}{l}410 \\
7\end{array}$ & 312,6 & $\begin{array}{l}269 \\
7\end{array}$ & $\begin{array}{l}401, \\
9\end{array}$ & $\begin{array}{l}561, \\
5\end{array}$ & 566 & 594 & $\begin{array}{l}584, \\
3\end{array}$ & 524,7 & 501,7 & 426,2 & 417,8 \\
\hline USA & 1227 & 1047 & 1069 & 1703 & 2179 & $\begin{array}{l}225 \\
7\end{array}$ & $\begin{array}{l}228 \\
3\end{array}$ & 2181 & $\begin{array}{l}2022, \\
7\end{array}$ & $\begin{array}{l}1909, \\
3\end{array}$ & $\begin{array}{l}1852, \\
3\end{array}$ & $\begin{array}{l}1886, \\
2\end{array}$ \\
\hline $\begin{array}{l}\text { China, P. } \\
\text { R. }\end{array}$ & 9,0 & 10,4 & 17,6 & 35,5 & 84,0 & 92,2 & 110 & $\begin{array}{l}124, \\
2\end{array}$ & 138,5 & 146,6 & 155,6 & 155,7 \\
\hline Japan & $\begin{array}{l}202, \\
2\end{array}$ & 389,7 & $\begin{array}{l}362, \\
4\end{array}$ & $\begin{array}{l}349, \\
8\end{array}$ & $\begin{array}{l}403, \\
5\end{array}$ & 422 & 473 & $\begin{array}{l}466, \\
9\end{array}$ & $\begin{array}{l}381,6 \\
8\end{array}$ & 367,8 & 324,7 & 365,4 \\
\hline $\begin{array}{l}\text { Korea, } \\
\text { South }\end{array}$ & $\begin{array}{l}235 \\
9\end{array}$ & 343,3 & $\begin{array}{l}293 \\
6\end{array}$ & $\begin{array}{l}460, \\
3\end{array}$ & $\begin{array}{l}496, \\
3\end{array}$ & 558 & 620 & $\begin{array}{l}633, \\
1\end{array}$ & $\begin{array}{l}675,5 \\
5\end{array}$ & 744,6 & 724,4 & 728,8 \\
\hline France & $\begin{array}{l}729 \\
2\end{array}$ & 802,3 & $\begin{array}{l}555 \\
1\end{array}$ & $\begin{array}{l}837 \\
6\end{array}$ & 1033 & 950 & 989 & $\begin{array}{l}914, \\
2\end{array}$ & $\begin{array}{l}961,1 \\
3\end{array}$ & 992,1 & 859,4 & 862,4 \\
\hline Germany & $\begin{array}{l}532 \\
8\end{array}$ & 503,9 & $\begin{array}{l}342, \\
4\end{array}$ & $\begin{array}{l}461, \\
5\end{array}$ & $\begin{array}{l}579, \\
5\end{array}$ & 566 & 589 & $\begin{array}{l}567, \\
7\end{array}$ & $\begin{array}{l}596,7 \\
9\end{array}$ & 571,7 & 493,4 & 509,3 \\
\hline Greece & $\begin{array}{l}314 \\
4\end{array}$ & 393,1 & 418 & 633 & $\begin{array}{l}942, \\
9\end{array}$ & 722 & 631 & $\begin{array}{l}524, \\
5\end{array}$ & $\begin{array}{l}527,6 \\
3\end{array}$ & 502,8 & 451,7 & 455,6 \\
\hline Italy & $\begin{array}{l}412 \\
2\end{array}$ & 340,9 & $\begin{array}{l}393, \\
6\end{array}$ & $\begin{array}{l}572, \\
1\end{array}$ & $\begin{array}{l}636, \\
2\end{array}$ & 596 & 628 & 554 & $\begin{array}{l}535,3 \\
9\end{array}$ & 528,1 & 423,0 & 467,4 \\
\hline $\begin{array}{l}\text { Netherland } \\
\text { s }\end{array}$ & $\begin{array}{l}496 \\
3\end{array}$ & 518,2 & 375 & $\begin{array}{l}586, \\
3\end{array}$ & $\begin{array}{l}733, \\
7\end{array}$ & 675 & 698 & $\begin{array}{l}631, \\
9\end{array}$ & $\begin{array}{l}614,7 \\
6\end{array}$ & 612,6 & 512,1 & 545,1 \\
\hline Norway & $\begin{array}{l}800 \\
4\end{array}$ & 804,7 & $\begin{array}{l}650 \\
6\end{array}$ & 1057 & 1283 & $\begin{array}{l}132 \\
9\end{array}$ & $\begin{array}{l}146 \\
0\end{array}$ & 1423 & $\begin{array}{l}1420, \\
3\end{array}$ & $\begin{array}{l}1424, \\
7\end{array}$ & $\begin{array}{l}1116, \\
0\end{array}$ & $\begin{array}{l}1138, \\
0\end{array}$ \\
\hline Russia & $\begin{array}{l}761, \\
6\end{array}$ & 86,01 & $\begin{array}{l}63,0 \\
7\end{array}$ & 191 & $\begin{array}{l}363, \\
1\end{array}$ & 412 & 491 & $\begin{array}{l}564, \\
9\end{array}$ & $\begin{array}{l}621,0 \\
2\end{array}$ & 590,5 & 463,0 & 483,1 \\
\hline Sweden & $\begin{array}{l}720 \\
8\end{array}$ & 649,1 & $\begin{array}{l}547 \\
9\end{array}$ & $\begin{array}{l}611, \\
1\end{array}$ & $\begin{array}{l}544, \\
5\end{array}$ & 628 & 669 & $\begin{array}{l}655 \\
6\end{array}$ & 676,6 & 675,6 & 550,9 & 540,2 \\
\hline $\begin{array}{l}\text { Switzerlan } \\
\text { d }\end{array}$ & 604 & 659,7 & $\begin{array}{l}389, \\
7\end{array}$ & $\begin{array}{l}468, \\
6\end{array}$ & $\begin{array}{l}523 \\
8\end{array}$ & 526 & 629 & $\begin{array}{l}574, \\
1\end{array}$ & 627,7 & 561,8 & 544,8 & 558,8 \\
\hline Turkey & $\begin{array}{l}98,4 \\
4\end{array}$ & 112,9 & $\begin{array}{l}158, \\
2\end{array}$ & $\begin{array}{l}178, \\
3\end{array}$ & $\begin{array}{l}226 \\
7\end{array}$ & 246 & 235 & $\begin{array}{l}244, \\
7\end{array}$ & $\begin{array}{l}249,5 \\
3\end{array}$ & 229,2 & 201,9 & 185,9 \\
\hline UK & $\begin{array}{l}680 \\
3\end{array}$ & 590,3 & $\begin{array}{l}598, \\
6\end{array}$ & $\begin{array}{l}915, \\
8\end{array}$ & $\begin{array}{l}936, \\
8\end{array}$ & 933 & 961 & $\begin{array}{l}925, \\
2\end{array}$ & $\begin{array}{l}907,9 \\
8\end{array}$ & 920,0 & 832,3 & 741,3 \\
\hline Israel & 1634 & 1545 & 1579 & 1552 & 1895 & $\begin{array}{l}193 \\
8\end{array}$ & $\begin{array}{l}199 \\
7\end{array}$ & 1905 & $\begin{array}{l}2036, \\
8\end{array}$ & $\begin{array}{l}2280, \\
5\end{array}$ & $\begin{array}{l}2078 \\
8\end{array}$ & $\begin{array}{l}2193, \\
8\end{array}$ \\
\hline Oman & 1067 & 936,6 & $\begin{array}{l}957 \\
8\end{array}$ & 1448 & 1686 & $\begin{array}{l}174 \\
6\end{array}$ & $\begin{array}{l}220 \\
4\end{array}$ & 3722 & & $\begin{array}{l}2585, \\
3\end{array}$ & $\begin{array}{l}2236 \\
9\end{array}$ & $\begin{array}{l}1953, \\
5\end{array}$ \\
\hline $\begin{array}{l}\text { Saudi } \\
\text { Arabia }\end{array}$ & 1009 & 710,9 & 991 & 1028 & 1540 & $\begin{array}{l}166 \\
0\end{array}$ & $\begin{array}{l}174 \\
8\end{array}$ & 1997 & $\begin{array}{l}2260, \\
9\end{array}$ & & & $\begin{array}{l}1978, \\
2\end{array}$ \\
\hline India & 12,1 & 10,2 & 13,6 & 20,2 & 31,9 & 37,4 & 39,8 & 37,4 & 37,0 & 39,3 & 39,1 & 42,1 \\
\hline Pakistan & 26,1 & 29,9 & 21,5 & 29,9 & 31,7 & 35,1 & 40,0 & 42,2 & 42,2 & 46,8 & 50,2 & 52,1 \\
\hline
\end{tabular}


Between 2007 and 2016, Oman has seen the biggest growth in military spending, with an increase of 123 percent, followed by China (118 percent) and Russia ( 87 percent). In the same period, Italy ( -16 per cent), the United Kingdom ( -12 per cent) and the United States $(-4.8$ per cent) were the only countries in the top 15 to see their military expenditure fall. While South Korea and Turkey also increased their spending, For much of the 2000s, military spending increased fairly rapidly in Brazil and India.

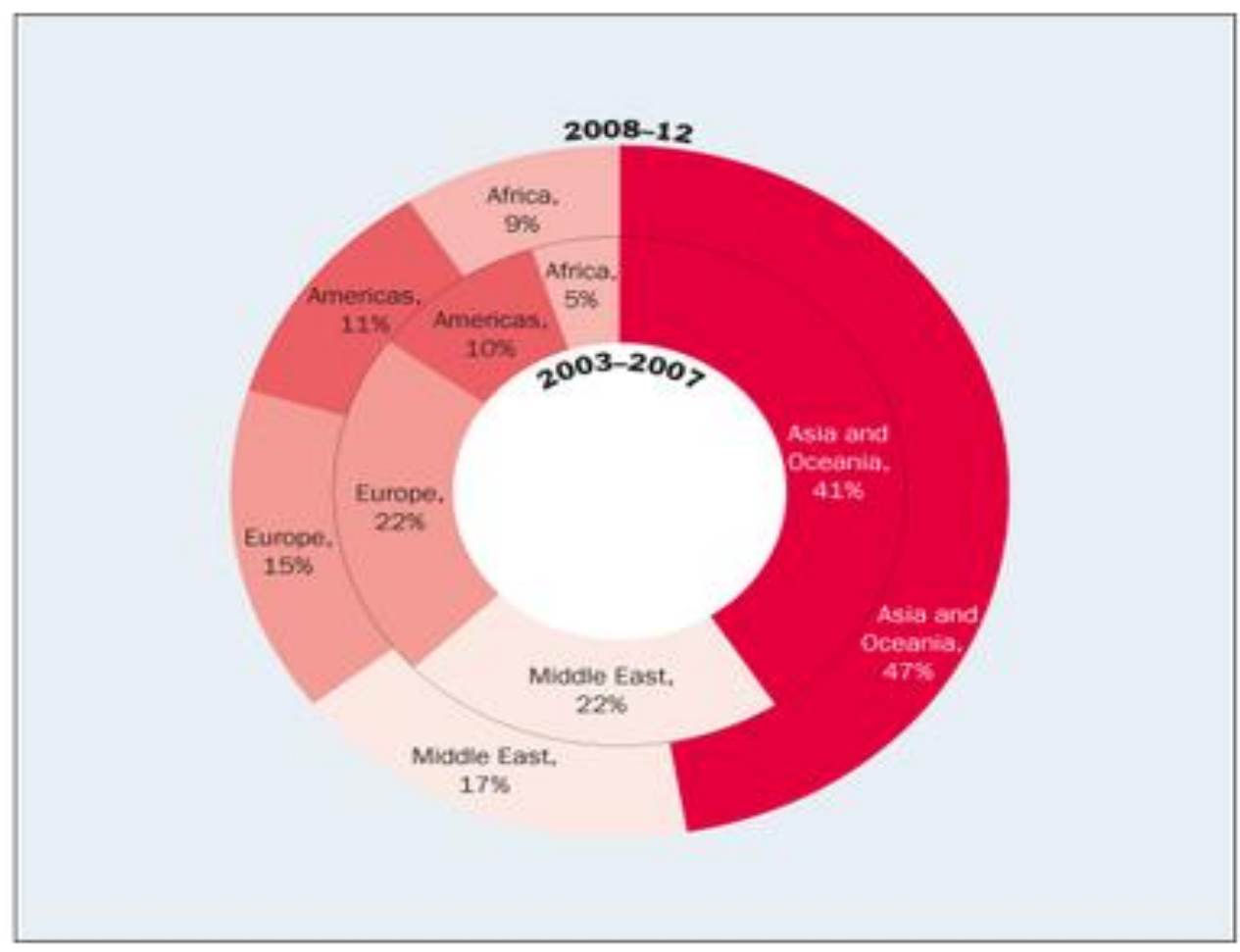

Figure 3. Major arms imports, 2003-2007 and 2008-12

Source: www.sipri.org/yearbook/2013/05

The biggest increases in military spending, 2004-13 A total of 23 countries have doubled their military spending in real terms since 2004. The countries are in all regions and subregions apart from North America, Western and Central Europe, and Oceania. Nearly all of the 23 countries display at least one of three characteristics: very strong economic growth, high oil or gas revenues, or significant armed conflict or other violence. In all cases, growth of military spending over the period was higher than growth in GDP (all in real terms) (see fig.3). Defense investments, indispensable character of the army "Quality people, superior doctrine, superior technology and ready forces", is focused. Economic power is the basis of military power. Defense investment determines the strength of the army (see table.2). 
Table 2. The Strongest 13 Army of The World (2014)

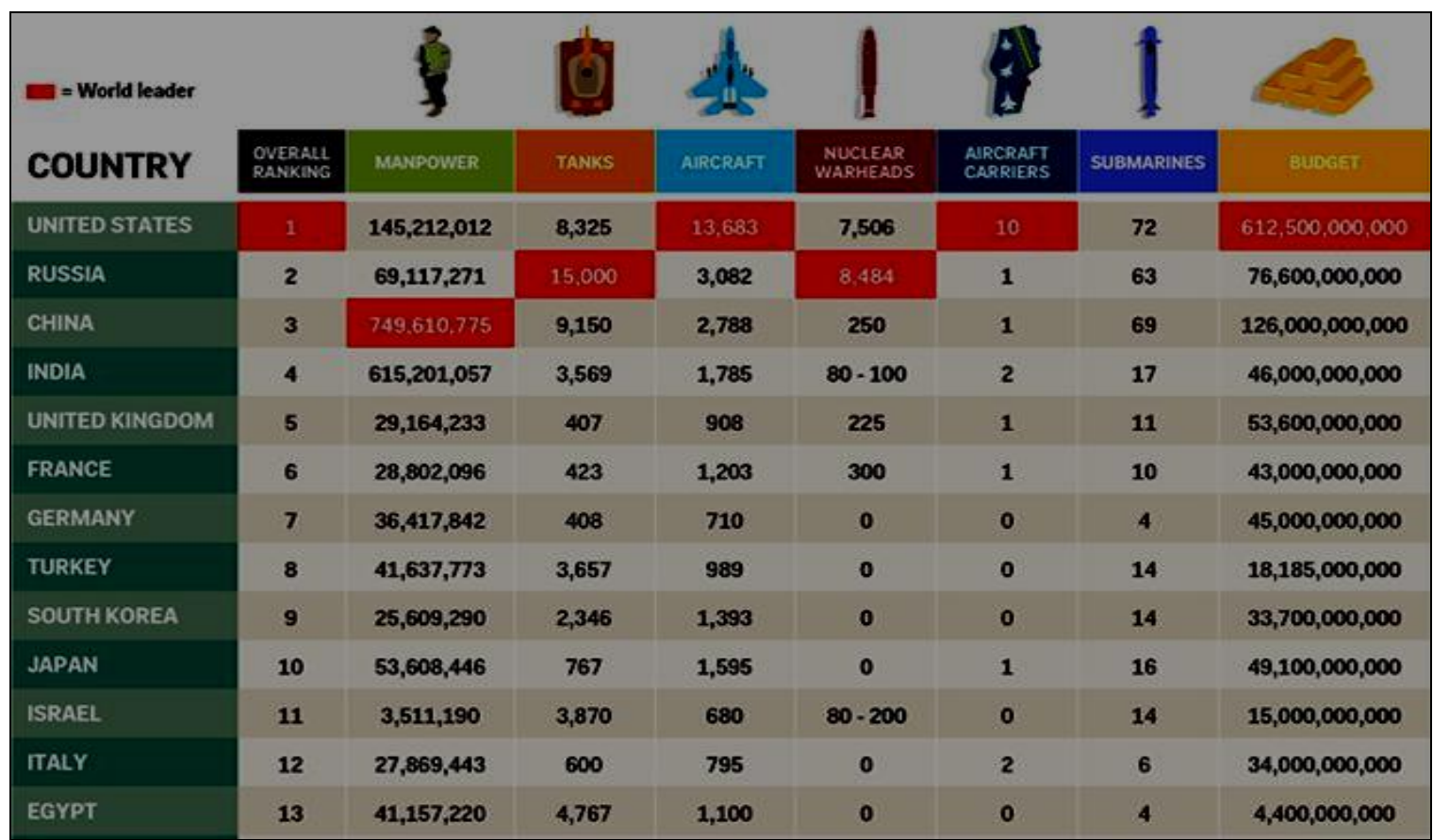

Source: Global Firepower-2014 World Military Strength Rankings. http://www.globalfirepower.com/ ; habertürk, http://galeri.haberturk.com/diger/galeri/439987-dunyanin-en-guclu-35-ordusu/1/25

The world's most powerful armies Global Firepower Index (2014) ranking; The US ranked first with more defense budget with most aircraft and ships, the second row Russia has the most nuclear weapons and tanks, China with most soldiers in terms of numbers is at three. Turkey is located eight intrinsically front of more budget with Japan and South Korea. While Turkey has kept position as eighth in 2016, France and UK changed position, Japan in $7^{\text {th }}$, Germany $9^{\text {th }}$, Egypt $10^{\text {th }}$, Italy $11^{\text {th }}$, S.Korea $12^{\text {th }}$ and Pakistan $13^{\text {th }}$ took in order. Table 3 , it is seen that gave considerable importance to China and the US defense industry.

Table 3. China and USA 2013, Estimation Military Expenditures 2040 (Billion \$)

\begin{tabular}{|c|c|c|c|}
\hline Country & 2013 & 2040 & $1988-2013$ \\
\hline USA & 612,5 & 1.013 & $10.919,6$ \\
\hline China & 126 & 295 & $1.310,4$ \\
\hline
\end{tabular}

Kaynak: Defense News, vol:20, no:38, p:70; SIPRI, http://milexdata.sipri.org

US defense spending in 2013, while approximately 612.5 billion dollars in 2040 is estimated to be over \$ 1 trillion this figure; The situation in China is foreseen to rise to one-half in 2040 compared to 2013. US defense spending in the years 1988-2013 was carried out about 11 Chinese defense spending, while USD 1.31 USD tirillion. Like the US and Russia has proved to be a country with a military mobility in space (Vago, 2007). The world's most powerful army with the US except for humanitarian operations throughout the world, especially between the years 1990 to 2003 were carried out military operations in nearly 50 countries (Trowbridge, 2005). Total defense spending by the United States between the years 19882013 is approximately $\$ 10.92$ trillion. Defense industry in the US is protected by special legislation.Israel's defense industry, the total defense expenditure for export as well as for their armies has invested $\$ 1.2$ billion in the amount of $24 \%$ of R\&D. Israel, its industry as an 
international arms dealer began to finance by external sources. Remote sensing satellite technology provides economic benefits largely to China.

European defense companies, instead of being combined with the large foreign companies have chosen to establish certain areas of joint-stock companies. These partnerships provide technological synergies and economies of scale. Instead of multinational companies in Europe, has increased the number of transnational corporations. The number of members of NATO is 26. According to NATO's mandate: - to meet asymmetric threats in the region and to ensure the security dialogue, exchange of experience in the construction of democratic structures, • military education, training and exercises, $\bullet$ border security and light weapons against human trafficking, • combating the proliferation of Weapons of Mass Destruction, - fight against terrorism, $\bullet$ civil emergency planning, $\bullet$ security of energy line, $\bullet$ scientific and environmental cooperation.

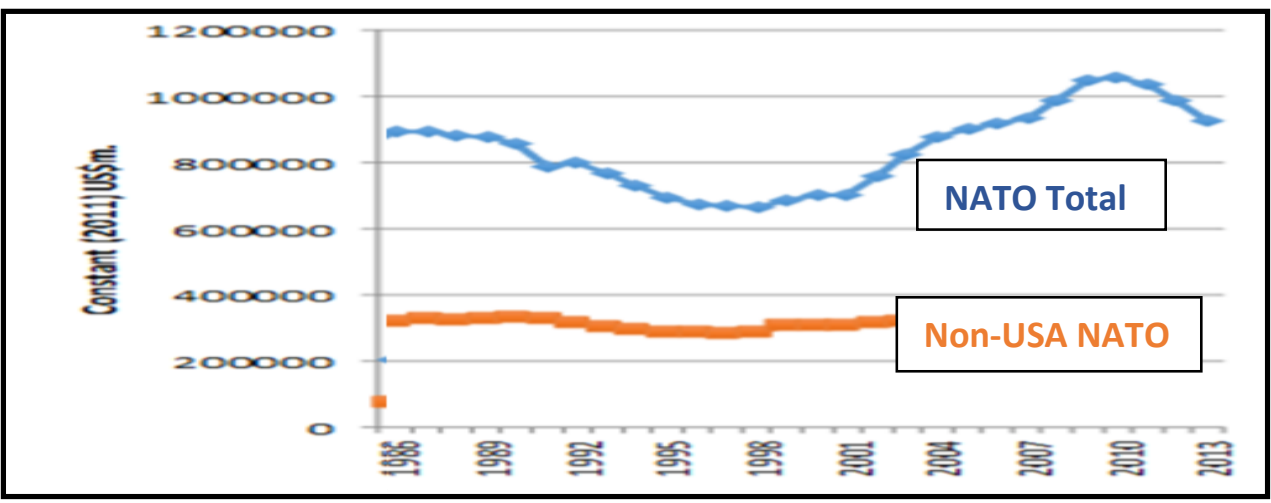

Figure 4. NATO Defense Spending (1986-2013)

Source: SIPRI, http://milexdata.sipri.org

Falling per capita defense spending in NATO countries, while 908 dollars per capita defense spending in the world per capita is US \$ 173. USA's obvious impact on NATO defense spending.(see fig.4) Most defense products to 10 countries exporting and importing countries (see table.4) is analyzed;

Table 4. The main importers and exporters of major arms (2010-2014)

\begin{tabular}{|l|c|l|c|}
\hline \multicolumn{1}{|c|}{ Exporter } & $\begin{array}{c}\text { Global } \\
\text { share }(\%)\end{array}$ & \multicolumn{1}{c|}{$\begin{array}{c}\text { Importer } \\
\text { Global } \\
\text { share (\%) }\end{array}$} \\
\hline USA & 31 & India & 15 \\
\hline Russia & 27 & Saudi Arabia & 5 \\
\hline China & 5 & China & 5 \\
\hline Germany & 5 & UAE & 4 \\
\hline France & 5 & Pakistan & 4 \\
\hline UK & 4 & Australia & 4 \\
\hline Spain & 3 & Turkey & 3 \\
\hline Italy & 3 & USA & 3 \\
\hline Ukraine & 3 & South Korea & 3 \\
\hline Israel & 2 & Singapore & 3 \\
\hline Source & 3 & & \\
\hline
\end{tabular}

Source: http://www.sipri.org/yearbook/2015/010

Between the years 2010-2014 taken by the United States rank first with $31 \%$ share of exporters world weapons, Russia, China, Germany and France followed him, while imports for the first row of India, then Saudi Arabia, China, UAE and Pakistan seems to follow him. Of the world's most powerful army on first and second with USA and Russia the main weapon in world exports in 2014 has made more than half. SIPRI estimates the total value of 
the global arms trade in 2013 to be at least $\$ 76$ billion. However, the true figure is likely to be higher.

\subsection{Reconstruction of Turkey's Defense Industry}

Acording to level of risk risk and threat levels, Turkey's development, growth of the economy, the more peace and defense issues to be considered for optimization based on while defensive investments necessary to ensure deterrence can be listed as follows:

-National defense industry should be developed in the US and the EU in the defense industry, as did the first by going to a big national company mergers should be created;

-Science and Technology should support the development of infrastructure; R \& D should be given priority by the shape of the supply;

-In cooperation with the University of skilled labor to be provided; Strong defense industry and should be a deterrent; Privacy and so big and strong national main contractor to ensure the reliability of each sub-sector companies should be determined in advance;

-Defense industry products, services should be opened to the industry; Brain drain to foreign countries, which should be prevented;

-Energy and raw materials should be evaluated in a rational way; Should avoid the high cost of production by preventing waste of resources;

-Sub-sectors should be made on the basis of a new structure;

-With economic integration should go to the consortium of major weapons systems;

-Foreign partner firms operating in Turkey should be examined very carefully, and that foreign firms should be the maximum degree of benefit;

-Military and civilian defense industry products when installing the system should adopt a structure that can produce together;

-Affect industrialization, industrialization preferences regarding the factors and mechanisms must be in harmony with the defense industry;

-Reducing the unit cost of production to more rational use of economic resources, for it is the optimum size of the firm;

-System for at least the dependence on external reliable, safe and characteristics of national defense industrial policy should be to be confidential;

-SHP and a national defense industry and technology that have taken place based on the master plan needs to be done OYTEP and creating infrastructure, which is known to cause some investments in waste of resources should not go again; 
-Be directed to the exterior of the production, the creation of the defense industry may have with integrated heavy industry, not the establishment of new ones in the same area not yet achieved full capacity in a production unit;

-In Turkey as seen in European countries, it should go to the national main contractor enterprise applications, in the form of a pyramid below the main contractor, sub-contractor companies that may be found in other national or foreign partnership companies;

-Large number of sub-systems produced by other industries should be expressed to be combined with system integration capability;

-Turkey's population and in the number of troops in the region despite being one of the leading countries, has remained far behind its neighbors in terms of per capita military spending, military and people.

Turkey should restructure the defense industry and should give priority to R \& D investment, due to its strategic position in the space should invest their efforts to be a leader in its geography and Turkish Space Agency should be established as soon as possible.

\section{Findings and Discussions}

This economic reasons referred to outline indicate it would be necessary to invest in Turkey's defense industry. In fact, even if none of these of these economic reasons, the threats found in the environment in Turkey's geopolitical position, is exposed in the past and in the future encounter with a potentially embargoes, reveals precisely the need to restructure the defense industry. Employment for 1.8 million refugees who fled the civil war in Syria in 2014, the amount of aid given to housing and health care is over 4 billion USD; This, Turkey's defense exports in 2013, was about four times without any export of defense in 1995. Defense investments that must be made due to the geopolitical should be optimized to provide economic, military, technological and political progress.

Geographical location of the country is one of the most important issues affecting their defense investments. A strong investment aimed at improving the country's defense industry must be directed to increasing the efficiency issue. Defense needs of a country is closely associated with its geostrategic position. Thus, according to the needs of the Army, Navy and the optimal level of investment will be allocated to other police forces will be determined by the Air Force, military effectiveness can be achieved. Floor area of the country and the length of the border is one of the most important issues affecting their defense investments. Amount of land area of the country and borders / coastline length is proportional to the defense investments. Because it increases the excess of their country's defense investments. In this context, it will not spend the landlocked country's maritime defense, defense investments will be directed to alternative investments. In addition, historical and cultural structure of the country is also a feature that may affect their defense investments. Because of this historical and cultural background, the views and the army on military investments may affect the country's leadership recognizes the priorities.

Country's risk and threat perception is one of the most important factors affecting the level of defense investment. The end of the Cold War and left the location of the risk factors perceived threat after the 2001 terrorist attacks and create a major transformation as a result of their defense strategy (Dinçyürek, 2005). New conditions for the sovereign-state status equal 
Afghanistan, North Korea, Palestine, Iraq intervention and new forms of intervention that took place in Kosovo, as can be seen in examples such as Cuba and Venezuela have made it necessary to restructure the defense industry. Defense spending of neighboring countries is one of the most important issues affecting their defense investments. Turkey; political, ethnic, water, oil and so on. dominated as it is the case of conflict of interest near neighbors of the country. Muezzinoglu (2014) was announced that the European aid to 130 thousand Syrians 200 million euros. Due to the neighbor, the amount of aid given all to housing and health care and employment for 3.5 million refugees who fled the civil war in Syria, is over 25 billion USD (Soylu, 2017). Look at defense spending to GDP ratios with neighboring countries in Table 5, below we state countries with the highest defense spending relative to that seen in Turkey's neighbors Russia. The regime change of the water problem, a number of security aspects of a potential attack source by dividing the federal formation extending into different concerns and different threats, Turkey constitutes the national security sensitivity (Hacısalihoğlu, 2004).

Table 5. Turkey and Neigbors' Defense Spending Ratio to GDP (2000-2013)

\begin{tabular}{|l|l|l|l|l|l|l|l|l|l|l|l|l|l|l|}
\hline Country & 200 & 200 & 200 & 200 & 200 & 200 & 200 & 200 & 200 & 200 & 201 & 201 & 201 & 201 \\
\hline Armenia & 3,6 & 3,1 & 2,7 & 2,7 & 2,7 & 2,9 & 2,9 & 3 & 3,4 & 4,2 & 4,3 & 3,9 & 3,8 & 4 \\
\hline Azerbaija & 2,3 & 2,3 & 2,2 & 2,4 & 2,6 & 2,3 & 3,4 & 2,9 & 3,3 & 3,3 & 2,8 & 4,7 & 4,7 & 4,7 \\
\hline Bulgaria & 2,7 & 2,9 & 2,9 & 2,8 & 2,6 & 2,4 & 2,3 & 2,5 & 2 & 2 & 1,9 & 1,5 & 1,6 & 1,6 \\
\hline Cyprus & 3 & 3,4 & 2,3 & 2,2 & 2,1 & 2,2 & 2,1 & 1,9 & 1,8 & 2 & 2,1 & 1,9 & 1,8 & 2,1 \\
\hline Georgia & 0,6 & 0,7 & 1 & 1,1 & 1,4 & 3,3 & 5,2 & 9,2 & 8,5 & 5,6 & 3,9 & 3,2 & 2,9 & 2,8 \\
\hline Greece & 3,6 & 3,4 & 3,2 & 2,6 & 2,7 & 2,9 & 2,9 & 2,8 & 3,1 & 3,3 & 2,7 & 2,4 & 2,3 & 2,4 \\
\hline Russia & 3,6 & 3,8 & 4,1 & 3,9 & 3,5 & 3,6 & 3,5 & 3,4 & 3,3 & 4,1 & 3,8 & 3,7 & 3,9 & 4,1 \\
\hline Turkey & 3,7 & 3,7 & 3,9 & 3,4 & 2,8 & 2,5 & 2,5 & 2,3 & 2,3 & 2,6 & 2,4 & 2,2 & 2,3 & 2,3 \\
\hline Iran & 3,8 & 4 & 2,5 & 2,8 & 3,1 & 3,5 & 3,5 & 2,7 & 2,1 & 2,2 & 2,2 & 2,1 & 1,9 & $\ldots$ \\
\hline Iraq & $\ldots$ & $\ldots$ & $\ldots$ & $\ldots$ & 1,7 & 2,2 & 1,9 & 2,2 & 2,2 & 2,7 & 2,6 & 3,3 & 2,8 & 3,6 \\
\hline Syria & 5,5 & 5,5 & 5,4 & 6,2 & 5,5 & 5 & 4,4 & 4,1 & 3,6 & 4 & 4,1 & $\ldots$ & $\ldots$ & $\ldots$ \\
\hline Source:SIR
\end{tabular}

Source:SIPRI, http://milexdata.sipri.org/result.php4

Country of foreign policy and defense strategies affect investment. Turkey's Defence Policy is "swallowing the Peace, Peace in the World" and "Zero Problems With Neighbors" as a part of "sustainable improvements" strategy. Acording to this, the main objective is making defense investment on time to support economical growth and social development with various reasons such as reducing import, dependency at defense, providing energy supply safety, diminishing possible load on balance of payment, compensating Deficits, increasing the productivity, providing employment, producting with minimum cost, supply-demand equilibrium of defense. Sovereignty doctrine of the industrialized and developed countries is one of the most important factors affecting the large level of defense investment. Historical ideals of the country and is a major factor shaping the defense industry investment quest for domination over the world.

International relations of the country one of the most important factors affecting the level of defense investment. Country has an intense interaction between defense strategies with international relations. Ensuring the protection of national security and national interests, it is possible to have the ability to develop and produce defense systems. Founded in defense activities with foreign countries; Co-production, Transfer of technology, Long-term loans, Know-How, Guaranteed sales to third countries, Employment, Providing foreign currency to 
the country, Like additional resources, Political, considering factors such as military and economic benefits, and priority should be given priority countries are determined.

GATT and the only area of the country they were exempt from all these decisions are aimed at the liberalization of goods and services for defense procurement. European market in defense, the defense industry in developed countries, now national main contractor companies are available for each sub-sector and supply policies are followed, even off against each other. Turkey maintains its position as the axis of the country to the United States. In accordance with Far East countries in Turkey's defense industry cooperation activities in the area, especially at the highest level there is full agreement with Pakistan. It needs to use the advantages afforded similar weapon systems as well as historical ties with S.Korea are joint technical cooperation facility on the occasion. Within the defense industry cooperation agreement with China has been continuing contacts (Gönül, 2007). Marketing capabilities of the country's defense products is one of the most important factors affecting the level of defense investment. The current condition of the system for the export of defense system of the country is produced is used in the army. (This is called 'Seal of Approval' rule is called.) Participation in international fairs Defense Industry companies of nations is an important dimension of marketing activities. The most important of the international defense industry exhibition 'Farnborogh (UK), Comdef (USA), Paris Air Show (France), Euro Satory (France), IDEX (United Arab Emirates), MSPO (Poland) and IDEF (Turkey).

The income level is one of the most important issues affecting defense investment. The population of the country is one of the most important issues affecting their defense investments. Level of development of the country is one of the most important issues affecting their defense investments. High-tech countries (critical technology) and R \& D is one of the most important factors affecting the level of defense investment. No country will refuse to other countries outside of critical military technology consisting of the most advanced technologies crucial situations. Increasing the benefits to the economy of the R \& D activities will be accelerated with the development of the defense industry are as follows: More effective use of resources; Prevention of brain drain and the exploitation of qualified labor; Ensuring product quality and increase standardization; Not only new investment but also more effective use of existing capacity and also the dissemination of new technologies throughout the country; Is to enhance the competitiveness and export opportunities in foreign markets.

Developing complex weapon systems, capable of producing and selling without being dependent on the number of countries that it is very limited. Even today, the traditional armsproducing countries in the area between France and England is taking technical assistance from the United States. In weapons production, an important indicator of the self-sufficiency rate is the domestic production in a given weapon system. Turkey in 2002, while 24\% in 2013 and $52.1 \%$ at level. Modern weapons are systems with high technology. Even a $1 \%$ share of foreign companies in the defense industry, if available in the field of critical defense technologies, the risk is very important. Highly skilled labor is one of the most important issues affecting defense investments. Expensive and intelligent systems with the high quality standards of the country is one of the most important issues affecting their defense investments. According to MSB (2014), there are 60 institutions having the AQAP document in Turkey.

Regarding company size, there is a benefit to signal to the merger. A number of large companies in various European defense market in parallel with the merger of the country are 
creating larger companies and joint working group between their combined(Ziylan, 1999). In the 1950s, operating in Germany in the field of aviation 7 separate company formed by the merger of Deutsche Aerospace (DASA) group, which operates in the UK caused by 10 different companies of the merger of British Aerospace, Aerospatiale formed by 6 different companies together in France represents an example. Today's 5 largest US defense company Lockheed Martin, Boeing, Northrop Grumman, Raytheon, Litton, 14 years ago, was 51 separate companies. Lockheed with Martin Marietta merger of the company with an annual savings of $\$ 1.8$ billion in US, in the 1993 world rankings with sales of $\$ 10$ billion, the largest first company 'Lockheed Corp., the fourth-largest company with $\$ 6.3$ billion in sales' Martin Marette 'with merged in 1995, Lockheed Martin' was the name. In 1997, McDonnell Douglas merged with Boeing.(see table.6)

Table 6. World Defense Revenue of The First 20 Firms (million US\$)

\begin{tabular}{|c|c|c|c|c|c|c|c|}
\hline Rank & Company & Country & $\begin{array}{l}2016 \\
\text { Defense } \\
\text { Revenue }\end{array}$ & $\begin{array}{l}2015 \\
\text { Defense } \\
\text { Revenue }\end{array}$ & $\begin{array}{l}\text { Defense } \\
\text { Revenue } \\
\text { Change\% }\end{array}$ & $\begin{array}{l}2016 \text { Total } \\
\text { Revenue* }^{*}\end{array}$ & $\begin{array}{l}\text { Revenue } \\
\text { From } \\
\text { Defense }\end{array}$ \\
\hline 1 & $\begin{array}{l}\text { Lockheed } \\
\text { Martin }{ }^{1}\end{array}$ & U.S. & $\$ 43,468.00$ & $\$ 40,596.00$ & $7 \%$ & $\$ 47,248.00$ & $92 \%$ \\
\hline 2 & Boeing & U.S. & $\$ 29,500.00$ & $\$ 30,388.00$ & $-3 \%$ & $\$ 94,571.00$ & $31 \%$ \\
\hline 3 & BAE Systems $^{2}$ & U.K. & $\$ 23,621.84$ & $\$ 25,278.08$ & $-7 \%$ & $\$ 25,867.20$ & $91 \%$ \\
\hline 4 & $\begin{array}{l}\text { Raytheon } \\
\text { Company }{ }^{1}\end{array}$ & U.S. & $\$ 22,384.17$ & $\$ 21,619.71$ & $4 \%$ & $\$ 24,069.00$ & $93 \%$ \\
\hline 5 & $\begin{array}{l}\text { Northrop } \\
\text { Grumman }\end{array}$ & U.S. & $\$ 20,200.00$ & $\$ 17,600.00$ & $15 \%$ & $\$ 24,508.00$ & $82 \%$ \\
\hline 6 & $\begin{array}{l}\text { General } \\
\text { Dynamics }\end{array}$ & U.S. & $\$ 19,696.00$ & $\$ 19,148.00$ & $3 \%$ & $\$ 31,353.00$ & $63 \%$ \\
\hline 7 & Airbus & Neth./France & $\$ 12,321.00$ & $\$ 12,776.10$ & $-4 \%$ & $\$ 73,903.80$ & $17 \%$ \\
\hline 8 & $\begin{array}{l}\text { L3 } \\
\text { Technologies }\end{array}$ & U.S. & $\$ 8,879.00$ & $\$ 8,772.00$ & $1 \%$ & $\$ 10,511.00$ & $84 \%$ \\
\hline 9 & Leonardo ${ }^{4}$ & Italy & $\$ 8,526.22$ & $\$ 9,318.45$ & $-9 \%$ & $\$ 13,322.22$ & $64 \%$ \\
\hline 10 & Thales & France & $\$ 8,362.00$ & $\$ 7,863.24$ & $6 \%$ & $\$ 16,837.00$ & $50 \%$ \\
\hline 11 & Almaz-Antey & Russia & $\$ 7,412.90$ & $\$ 6,965.77$ & $6 \%$ & $\$ 7,412.90$ & $100 \%$ \\
\hline 12 & $\begin{array}{l}\text { United } \\
\text { Technologies }\end{array}$ & U.S. & $\$ 6,888.00$ & $\$ 6,780.00$ & $2 \%$ & $\$ 57,400.00$ & $12 \%$ \\
\hline 13 & $\begin{array}{l}\text { Huntington } \\
\text { Ingalls } \\
\text { Industries } 1\end{array}$ & U.S. & $\$ 6,778.21$ & $\$ 6,879.60$ & $-1 \%$ & $\$ 7,068.00$ & $96 \%$ \\
\hline 14 & $\begin{array}{l}\text { United Aircraft } \\
\text { Corp. }{ }^{1}\end{array}$ & Russia & $\$ 5,636.84$ & $\$ 4,643.76$ & $21 \%$ & $\$ 7,046.05$ & $80 \%$ \\
\hline 15 & Rolls-Royce & U.K. & $\$ 4,741.15$ & $\$ 4,790.28$ & $-1 \%$ & $\$ 18,675.97$ & $25 \%$ \\
\hline 16 & Textron Inc. & U.S. & $\$ 4,412.16$ & $\$ 4,161.13$ & $6 \%$ & $\$ 13,788.00$ & $32 \%$ \\
\hline 17 & Honeywell $^{5}$ & U.S. & $\$ 4,375.00$ & $\$ 4,715.00$ & $-7 \%$ & $\$ 39,302.00$ & $11 \%$ \\
\hline 18 & Leidos & U.S. & $\$ 4,252.00$ & $\$ 3,248.00$ & $31 \%$ & $\$ 7,043.00$ & $60 \%$ \\
\hline 19 & Hanwha ${ }^{6}$ & S.Korea & $\$ 4,214.97$ & $\$ 3,104.00$ & $36 \%$ & $\$ 40,523.38$ & $10 \%$ \\
\hline 20 & $\begin{array}{l}\text { Harris } \\
\text { Corporation }\end{array}$ & U.S. & $\$ 4,213.00$ & $\$ 4,400.00$ & $-4 \%$ & $\$ 5,950.00$ & $71 \%$ \\
\hline
\end{tabular}

Source: http://people.defensenews.com/top-100/

The top 20 companies in the ranking world's largest defense companies; such as 12 US, 2 UK and 2 Russia, 1 France, 1 Netherlands/France, 1 Italia and 1 S.Korea. Here, striking another factor that firms make production of civilian and military purposes. Turkey has 3 companies in top 100 firms; respectively, Aselsan( 57), TAI (61) and Roketsan (98).

Restructuring process in the defense industry is a dual-use products (Haşıloğlu \& Haş1loğlu, 1999). Internet, although developed for military purposes had been used in the information 
society in the last decade of the twentieth century has been the main actors of the information and communication age. In the construction of nuclear reactors used in the production of electrical energy used for commercial purposes, are examples of the use of commercial areas developed internet and satellite for military purposes. Economic point of view, the defense industry; economy, stimulating, invigorating and accelerator effects due to form holds an important place among other industries.

Project-based production of the country is one of the most important issues affecting their defense investments. Atomic Bomb Project in 1940 with structured project-based management style, then became an indispensable feature of the defense industry with the development of private technology companies in the construction of nuclear submarines.

As long as Countries are quite, their defensive investments / expenditures long. Therefore, the defense industry 'elasticity of demand' can be considered as a market low. War or peace situation of the country stands out as the most important factor (Raghuvanshi, 2007). Supplydemand relationship, which applies to all other economic systems are also valid for the defense industry products. On the demand side often has the state as the sole buyer has formed an oligopoly of large enterprises on the supply side. Therefore, product quality and price can be adjusted as desired. In this competitive market, where in the Turkey, manufacturers increasingly monopolizing the day they go to the country and is observed to determine strategies in this direction. Particularly mergers taking place in Europe and the United States are the most beautiful examples

F-16 is one of the best-selling aircraft. For example, Vigor-gen Saab combat aircraft can not find enough market cost of F-16 triples, again if the price of the Dassault Rafale aircraft F-16 has reached the doubles. Israeli war planes have the technology to produce too high of Kfir aircraft experiment was terminated, the production cost reasons. A Tornado aircraft from Germany, Italy and the real basis behind the UK's create together is to hold large market share. In fact, this aircraft was unable to find sales opportunities outside their Air Force. With Economy of Scale has produced over 10,000 units of F-16 jet fighter cost is relatively low. F35 fighter aircraft is the best example of joint production.

Energy and raw materials is one of the most important issues affecting the defense investment of countries. Therefore, both reliable and cheap supply of raw materials and energy resources in peace and in war period is vital.

Critic inventory and storage is one of the most important issues affecting the countries' defense investments. Some countries have had difficulties due to the current need to have a minimum amount of stock in the so-called critical stock. An important feature of the raw materials used in the defense industry is that it requires a very high energy. However, reaching the highest point in the increasing cost of oil and other energy sources even war period. It is also difficult to provide the continuity of the energy source. Seems to be quite a long period of use of defense products. As a result, important parts subject and should be provided in time can exceed 30 years in some cases. Improvement in intervals (upgrade) is required. Now it is used for a long time without the improvement of a product cycle is closed. This method is more cost-effective solution in terms of customers. Modernisation is one of the most important issues affecting the modernization of defense investment in the last 10 years, the Internal Military Modernization efforts have gained importance. In fact, the Gulf War, he served more than 4000 staff in the various American companies to support the maintenance of the system itself battlefield. (Ziylan, 1998) 
Country of political elements are one of the most important issues affecting their defense investments. Political preferences and management style affects the amount of the share devoted to military expenditure in the country. A country at war inevitably will increase the demand for military expenditure.

Today, when Orion's travel and space mining discussed, Vision 2023 is one of the most important aspects that determine the direction of defense investment for Turkey.

\section{Conclusions}

From 1945 to Orion travel, extraordinary developments occurring in military technology has significantly changed the logic and culture of the defense industry. Parallel to this threat perception is changing. Defense industry was restructured in line with the new strategies. Economy has gained weight in the defense industry. The end of the cold war and terrorism macro-induced dark war made it necessary restructuring in the defense industry. Due to the survival of the country's, defense investment and defense spending is an obligation to do. If the security of a country's defense is unsufficient, at the same time the other investment will remain at an insufficient level. Therefore, defense spending or investment is important. Therefore, investment in the defense industry which will be rational and should be evaluated in economic figures, political, military, should be planned to provide economic and social benefits.

Defense industry is an important branch of economic activity in the world's, first as seen in the export of defense industry products taken by developed countries. The value added, employment, direct and indirect contributions, capacity utilization and positive impact on other sectors linked to the defense, payments on long-term effects will create a positive balance, demonstrates the significant economic importance of the defense industry.

After the military purpose-built defense equipment is used for civilian purposes and the economic context has been shown to increase the level of welfare. Is the dual nature of defense equipment. In the construction of nuclear reactors used in the production of electrical energy used for commercial purposes, are examples of the use of commercial areas developed internet and satellite for military purposes. Economic point of view, the defense industry; economy, stimulating, invigorating and accelerator effects due to form holds an important place among other industries.

Prevention is the most effective element of the defense. World of uncertainty, risk and threat environment requires the existence of a deterrent defense power. Increasing the effectiveness of the country as a regional power, which is based on high-tech, dynamic and depends on the defense industry supported by a self-sufficient.

Science and technology in the country that produces a rapidly changing world, the use of national resources by themselves, as it is one of the fundamental requirements of independence, but also meant to be prepared for unexpected threats. The most important feature of defense products, when the need for the product, can not be known beforehand where and under what conditions will occur. Production to raise the technological level; the use of advanced technology, research and development activities, education, offset agreement and priority should be given to the highest quality standards. R \& D based on a defense, as scientific and technical dimension, are also considered to be a contribution to economic development and social welfare. In the event of merger of the companies operating in the 
defense sector in Turkey, the country will benefit from a huge benefit as the EU and in the US for a strong defense.

Turkey is located on an extremely important geopolitical and geostrategic terms of geography. When examining the history of this land has hosted many civilizations, the most important results that emerged; poor states have no chance to live in this region. Turkey in the future to make it stable and powerful military and economic aspects, it is possible with an advanced defense industry. Turkey, however, the results of national defense in the event of Cyprus in 1974, the strategic disadvantages posed by dependence on external sources of supply, such as military aid has experience in a painful way.

Products in the defense industry as well as for both military and civilian purposes civilian products can also be used for military purposes. Produced new designs can be added to the main system can be modified again and technological innovations can be used through different purposes. The overall integration of the defense industry, produced the technology also makes it possible to use in civilian areas, defense production can also be achieved thanks to the dual use of the economic scale. Another feature is to be integrated as well as general industry integration international industry. Today, major defense contractors is usually the case system integrator. Even if they were manufactured within the country for some subsystems that make up the main system, producing intermediate goods more cheaply are able to supply from other countries. Therefore, system integrators, the product should be integrated with industry international order to produce the most economical way. This integration is also a necessary condition to be able to export.

Defense investments, the world globalization, countries of the technologies of political and socio-economic structure of the border are affected by the embodiments of the country's defense industry and geographic location. All of the countries around Turkey, devotes more resources to defend. They are located in the geographic, economic, political and security factors are ethnic and religious ties with major international defense market factors that determine the structure. Export and import of defense systems carried out in this context determines the trading volume of the international defense market. Defense is based on the principle of always being ready to be used when needed. Always ready and be strong, the most important requirement is deterrence. Turkey's exposure to threats and makes it mandatory to have the weapons and defense systems that require high technology. Defense industry, can not be considered separately from the general industry of the country by a defense that can not be integrated with the general industry of the country, to do with the high cost of production and will lead to a waste of resources.

Military systems are no longer obliged to intelligent systems and intelligent weapon would not trust anyone from strangers espicially unmaned vehicles. Therefore, in order to increase the technological level of production in Turkey; the use of advanced technology, research and development activities, education, offset agreement and priority should be given to the highest quality standards. These compensatory packages called offset, new foreign investments, joint production projects, technology and license transfers, domestic / international education, cash payments, $\mathrm{R} \& \mathrm{D}$ investments can be summarized time. This cooperation with alternative export opportunities and other compensatory processes. Offset is an indispensable part of defense contracts. $\mathrm{R} \& \mathrm{D}$ based on a defense, as scientific and technical dimension, are also considered to be a contribution to economic development and social welfare. 
As of 2016, the total volume of world defense industry, surpassed 1.68 trillion dollars. The 15 largest spenders account for $\$ 1360$ billion, or 81 per cent, of total global spending. Between 2007 and 2016, China has seen the biggest growth in military spending. Turkey sharing of $19 \%$ of the rest of the defense market is one of the 155 countries with a share of $0.8 \%$. Turkey should receive a share of this huge feeling in the defense industry. Defense spending because of its geographical position in the relatively short-Turkey should provide a variety of benefits by acting in a rational and economical way.

Changes in threat perception in the real world and has launched the world defense spending upward trend. Intense competition brought by globalization has necessitated the presence of a strong and large companies in the defense industry. In particular, macro-terrorism strategy and policy change that the country's defense and defense industry is a flexible structure for the threat level change and transformation is rapid mobility.

Defense is the industries that require high investment and high capital. Capital goods used in the defense industry complex structure, the special quality and expensive machines, factories, $\mathrm{R} \& \mathrm{D}$ laboratories, such as facilities and testing instruments consist of special equipment. Due to the mentioned properties of these goods require high levels of investment. Defense goods production costs high. In particular, input and leads to waste of resources in countries suffering a shortage of resources. War and competitive environment that can withstand more than it costs to acquire the defense industry. In this area, the Company's primary objective is not profit maximization.

In developed countries, as well as the rule provided in terms of military defense industry is a known fact that both in contributing to the overall economy and play an important role in political activity. Succeed on a global scale in this sector and have a say in the situation in the market come to Turkey can be advantageous in many respects. With the reconstructioning of the defense industry and the cleverly defense investment, military, technological, political, social and economic benefits can be obtained. Achieved through investment and restructuring in the defense sector will be the socio-economic benefits can be listed as follows: Military Aspects; i) Competence, increasing the reliability of weapons systems and to contribute to deterrence as a result, ii) Strategic and tactical decisions taken to ensure the implementation of activities, iii) take deterrent role in the solution of disputes, iv) Military standards appropriate to make production, contributing to the standardization of the TAF system, v) To have the ability to produce different solutions for problems. The Economic and Social Aspects; i) Reducing the potential burden on the national economy (Foreign entry, contributing to the balance of payments), ii) contribute to the competitiveness, iii) Ensuring employment growth, iv) The development of sub-industry, v) contribute to the reduction of inflation, vi) Increasing social welfare, vii) Rising standards of living. Technological Perspective; i) contribute to the enhancement of Turkey's science-tech talent, ii) contributing to the cooperation with scientific institutions of the industry. Political Perspective; i) To be a state leader in his own zone, ii) have a say in Internetional organizations, iii) to play an active role in solving the conflict.

The country's defense industry investments shortly, there is a delicate balance between macroeconomic indicators and political influence.

\section{References}

A.R.Chowdury, 1991. A Casual Analysis Of Defense Spending And Economic Growth. Journal of Conflict Resolution, Issue , pp. 80-97. 
Anon, (2014) Global Firepower-2014 World Military Strength Rankings. http://www.globalfirepower.com/

Benoit, E., (1978) Growth and defense in developing countries. Economic Development and Cultural Change, pp. 271-280.

Canan, J. W. (2004) Askeri Uzay Çalışmalarında Yeni Bir Çağ. Hava Kuvvetleri Dergisi, p. 11.

Caşın, H. (1995) Yüzyılda Uçakların Savaşı. Silahlı Kuvvetler Dergisi, Issue 344, p. 59.

Coşkun, B. (1998) Silahlanma, Az Gelişmişlik ve Yeni Dünya Düzeni. Macro, p. 98.

Çağlar, B. (2000) Havacılık Ve Savunma Sanayi Üzerine Çalışmalar. Ankara

Dinçyürek, A. (2005) Küresel Terör: Kurgulanmış Bir Egemenlik Aracı mı?. Stratejik Araştırmalar Dergisi, Issue 5, p. 4.

Dritsakis, N. (2004) Defense spending and economic growth: an empirical investigation for Greece and Turkey. Journal of Policy Modeling, p. 249-264. .

Efe, M. (2002) Türk Deniz Kuvvetleri Güçlenmeye Devam Ediyor-IV. Savunma ve Havacılık Dergisi, Issue 3, pp. 39-42.

Frederiksen, P. \& Looney, R. E. (1986) Defense Expenditures, External Public Debt and Growth in Developing Countries. Journal of Peace Research, 23(4), p. 329-337.

Gönül, V. (2007) Güvenlik ve İstikrar İçin Güçlü Ekonomi, Güçlü Savunma. Vecdi GÖNÜL, "Güvenlik ve İstikrar Iç̧in Güçlü Ekonomi, Güçlü Savunma”, Savunma ve Havacılık Dergisi, Issue 2007/02, p. 45.

Hacısalihoğlu, Y. (2004) Kuzey Afrika ve Orta Doğu'daki Kriz Kaynakları ve Bölgelerinin Türkiye'nin Güvenliğine Etkileri. Yaşar HACISALIHOĞLU, "Kuzey Afrika ve Orta Doğu'daki Kriz Kaynakları ve Bölgelerinin İstanbul, Genelkurmay Askeri Tarih ve Stratejik Etüd Başkanlığı Yayınları.

Haşıloğlu, A. \& Haşıloğlu, S. B. (1999) Internet Üzerinden Akıllı Kent Haritalarının Oluşturulması. Trabzon, http://www.gislab.ktu.edu.tr/yayinlar/KBS99/20_hasiloglu.doc.

Hewitt, D. P. (1991) What Determines Military Expenditures?. Finance and Development, pp. 22,23 .

MSB (2014) AQAP Endüstriyel Kalite Güvence Seviye Belgesi Verilen Kuruluşların Listesi. http://www.msb.gov.tr/AQAP/phpscr/AQAPARAMA.php

Müezzinoğlu, M. (2014) Sağlık Bakanı Mehmet Müezzinoğlu, Suriyelilere yapılan yardımın tutarını açıkladı. basım yeri bilinmiyor:Yeni Asya.

Oral, A. (2005) II. Dünya Savaşında Türk Yapısı Uçak Bombaları. Bütün Dünya Dergisi, Issue 9, pp. 20-23. 
Özsoy, O. \& İpek, E. (2010) The Relationship Between Defense Spending And Macroeconomic Variables. Internatilonal Journal Of Economics And Finance Studies, 2(1), pp. 103-111.

Perlo-freeman, S. \& Solmirano, C. (2014) SIPRI Fact Sheet. http://books.sipri.org/product_info?c_product_id=476\#

Raghuvanshi, V. (2007) To Overhaul Defence Financing. Defense News, February, p. 1.

SIPRI, Stockholm International Peace Research Institute, www.sipri.com

Trowbridge, G. (2005) Forward Thinking. Defense News, p. 46.

Vago, M. (2007) China's Mystery Satellites. Defense News, Issue 6, p. 1.

Ziylan, A. (1998) Savunma Sanayi ve Tedarik. Ankara: TÜBİTAK.

Ziylan, A. (1999) Savunma Sanayi Üzerine. Ankara. 